\title{
Performance of Photo Sensitive Rice cv. RNR 15048 (Telangana Sona) Under Varied Nitrogen Levels and Environmental Conditions
}

\author{
K. Nikitha ${ }^{1 *}$, G. Sreenivas ${ }^{2}$, P. Leela Rani ${ }^{3}$ and A. Madhavi ${ }^{4}$ \\ ${ }^{1}$ Department of Agronomy College of Agriculture, Rajendranagar, \\ Hyderabad PJTSAU, Telangana, India \\ ${ }^{2}$ Agro Climate Research Centre, ARI, Rajendranagar, Hyderabad, PJTSAU, Telangana, India \\ ${ }^{3}$ AICRP on Weed Management, Rajendranagar, Hyderabad, PJTSAU, Telangana, India \\ ${ }^{4}$ AICRP on STCR, ARI, Rajendranagar, Hyderabad, PJTSAU, Telangana, India \\ *Corresponding author
}

\section{A B S T R A C T}

\section{Keywords}

Photoperiod, Flowering, Basic vegetative phase

Article Info

Accepted:

28 February 2018

Available Online:

10 March 2018
Field experiment on "Performance of photo sensitive Rice $c v$. RNR 15048 (Telangana Sona) under varied nitrogen levels and environmental conditions" was carried out during Kharif 2016 at Agricultural Research Institute, Rajendranagar, Hyderabad. The experiment was laid out in split plot design with five dates of sowing [5 Jun $\left(D_{1}\right)$, 20 Jun $\left(D_{2}\right)$, 5Jul $\left(D_{3}\right)$, 20Jul $\left(D_{4}\right)$ and 5 Aug $\left(D_{5}\right)$ ] as main plots and two nitrogen levels $\left(\mathrm{N}_{1}: 120 \mathrm{~kg} \mathrm{~N} \mathrm{ha}^{-1} ; \mathrm{N}_{2}: 160 \mathrm{~kg} \mathrm{~N}^{-1}\right)$ as sub-plots replicated thrice. Flowering duration of rice was influenced by dates of sowing. With delay in sowing dates the days to attain flowering decreased with decrease in day length from 12.5 to $12.1 \mathrm{hrs}$. Crop sown on 5 Jun $\left(D_{1}\right)$ took more number of days to attain panicle initiation, heading and physiological maturity than other sowing dates. As the sowing dates got delayed, there was progressive decrease in days to attain panicle initiation, heading and physiological maturity.

\section{Introduction}

Rice (Oryza sativa L.) is one of the world's major staple food crops. Among the rice growing countries in the world, India has the largest area under rice crop (about 43.5 million ha) and ranks second in production about 104.92 million tones (2014-15) next to China which is about 207.44 million tones (FAO, 2014). Rice contributes $42 \%$ of total food grain production and $45 \%$ of total cereal production in India. Rapidly growing world population is fed on limited land, with limited input resource while there is increased cost of cultivation and increased poverty. So, it is necessary to go for increased food production mainly in case of rice as it is consumed in greater proportion world widely.

The introduction of photoperiod insensitive rice varieties during the sixties is a significant mile stone in the history of rice cultivation for the tropical countries. It has greatly helped in increasing rice production through scientific rice based cropping sequences. However, the crop production is the result of the 
coordinated interplay of genotype and environmental factors. Among the several climatic factors affecting rice production, temperature and solar radiation are the most important factors in the tropics, where temperature is usually not a limiting factor (Vergara, 1976), and solar radiation obviously became the major climatic factor limiting grain yield. Low rice yields during monsoon season in the tropics have been attributed to low light intensities as there is a positive correlation between yield and solar radiation (De Datta and Zarate, 1970).

Rice phenology such as panicle initiation, heading and flowering is determined by both temperature and photoperiod (Summerfield et al., 1992; Yin et al., 1997a, b). According to Vergara and Chang, 1985 post-PI photoperiod's exerted significant effect on rice development from PI to flowering stage although the effect was not as striking as on development before PI.

Recently in Telangana state, RNR 15048 (Telangana Sona) has been released as short duration fine grain variety resistant to blast and is highly photosensitive in nature. It performs well even under low nitrogen level. Due to these reasons, this variety has been popularising in entire Telangana State, some parts of Andhra Pradesh and Karnataka states. Besides these advantages, the varietal performance in the farmer's field varied from location to location, with staggered sowing dates and under different nitrogen levels.

The early sown crop showed excessive vegetative growth due to prolonged growth period leads to reduction in the yield. In all photosensitive varieties characters like days to heading, plant height and tillers per plant showed invariable trend of increment with the application of higher doses of nitrogen. The higher dose of nitrogen causes excessive vegetative growth leads to lodging of the crop along with decline in filed grains per panicle and yield (Rahaman, 2004). Under these circumstances, standardization of location specific optimum sowing date with suitable nitrogen levels is a need of hour.

\section{Materials and Methods}

An experiment was conducted during kharif, 2016 at Agricultural Research Institute, Rajendranagar, Hyderabad. The farm is geographically situated an altitude of $542.6 \mathrm{~m}$ above mean sea level on $18^{\prime} 50 \mathrm{o} \mathrm{N}$ latitude and $77.53^{\circ} \mathrm{E}$ longitude. The soil of the experimental site was sandy loam in texture, neutral in reaction, low in available nitrogen, phosphorus and high in available potassium.

The experiment was laid out in split plot design with five dates of sowing [5 Jun $\left(\mathrm{D}_{1}\right)$, 20 Jun $\left(\mathrm{D}_{2}\right)$, 5Jul $\left(\mathrm{D}_{3}\right), 20 \mathrm{Jul}\left(\mathrm{D}_{4}\right)$ and 5 Aug $\left.\left(\mathrm{D}_{5}\right)\right]$ as main plots and two nitrogen levels $\left(\mathrm{N}_{1}: 120 \mathrm{~kg} \mathrm{~N} \mathrm{ha}^{-1} ; \mathrm{N}_{2}: 160 \mathrm{~kg} \mathrm{~N} \mathrm{ha}^{-1}\right)$ as subplots replicated thrice. Crop prophylactic measures were taken as and when necessary. Days taken to attain each phenological phase across different dates of sowings were analyzed.

\section{Results and Discussion}

\section{Phenology}

Days taken to attain each phenological phase were influenced across dates of sowing of the rice $c v$. RNR 15048 (Table 1). Crop sown on 5 Jun $\left(D_{1}\right)$ took more number of days to attain panicle initiation, heading and physiological maturity than other sowing dates. As the sowing dates got delayed, there was progressive decrease in days to attain panicle initiation, heading and physiological maturity.

Number of days required for completion of vegetative phase for rice $c v$. RNR 15048varied when crop was sown on different dates. A decrease in the period of vegetative phase was observed with delay in sowing. 
Crop sown on 5 Jun $\left(D_{1}\right)$ taken more number of days (94 days) for completion of vegetative phase than 5 Aug ( $\left.D_{5}\right)$ sown crop (60 days), since rice is a short day plant (Dingkuhn and Miezan, 1995) which enter reproductive phase during the days of shorter photoperiod. So crop entered reproductive phase during the period of shorter photoperiod (12.1 hrs) when the crop sown on 5 Aug $\left(D_{5}\right)$, while in 5 Jun $\left(D_{1}\right)$ sown crop, it entered reproductive phase during the period of longer photoperiod (12.5 hrs). Similarly with delay in sowing number of days required for completion of flowering and maturity decreased. Thus it was observed that sowing date has significant influence on phenological events of rice $c v$. RNR 15048 . Thermal and photoperiodic conditions have a profound effect on rice phenological development and hence on growth and yield (Yoshida, 1981). Crop sown on 5 Jun $\left(D_{1}\right)$ needed $12.5 \mathrm{hrs}$ photoperiod for completion of its vegetative phase. Similarly Maiti and Sen (2003) observed that increasing trend of growth duration was exhibited in early planted crop and decreasing trend in late planted crop (Table 2).

Table.1 Phenology of rice $c v$. RNR 15048 at different growth stages Influenced by dates of sowing

\begin{tabular}{|l|c|c|c|c|}
\hline \multicolumn{1}{|c|}{ Date of sowing } & \multicolumn{3}{|c|}{ Days after sowing(DAS) } \\
\cline { 2 - 5 } & Transplanting & $\begin{array}{c}\text { Visible Panicle } \\
\text { initiation }\end{array}$ & Heading & $\begin{array}{c}\text { Physiological } \\
\text { maturity }\end{array}$ \\
\hline D $_{\mathbf{1}}$ - 5 Jun & 21 & 94 & 119 & 152 \\
\hline $\mathbf{D}_{\mathbf{2}}$ - 20 Jun & 21 & 82 & 108 & 141 \\
\hline $\mathbf{D}_{\mathbf{3}}$ - 5 Jul & 21 & 74 & 99 & 129 \\
\hline $\mathbf{D}_{\mathbf{4}}$ - 20 Jul & 21 & 66 & 90 & 123 \\
\hline $\mathbf{D}_{\mathbf{5}}$ - 5 Aug & 21 & 60 & 82 & 121 \\
\hline
\end{tabular}

Table.2 Basic vegetative phase (BVP) and photoperiod of rice $c v$. RNR 15048 as influenced by dates of sowing

\begin{tabular}{|l|c|c|c|}
\hline Date of sowing & BVP & Duration (Days) & Photoperiod (BVP) \\
\hline D $_{\mathbf{1}}$ - 5 Jun & 29-Aug & 85 & 12.5 \\
\hline $\mathbf{D}_{\mathbf{2}}$ - 20 Jun & 2-Sep & 74 & 12.4 \\
\hline D $_{\mathbf{3}}$ - 5 Jul & 8-Sep & 65 & 12.3 \\
\hline $\mathbf{D}_{\mathbf{4}}$ - 20 Jul & $14-$ Sep & 56 & 12.2 \\
\hline D $_{\mathbf{5}}$ - 5 Aug & $22-$ Sep & 48 & 12.1 \\
\hline
\end{tabular}

Suenaga (1936) recognized the basic vegetative phase (BVP) and measured it by taking the duration of the vegetative growth phase at optimum day length. The BVP also has been measured by subtracting 35 days from the growth duration (sowing to flowering) of plants grown at the optimum photoperiod (Vergara et al., 1965). This assumes that the period from panicle initiation to flowering is about 35 days.
The range of BVP has varied from 10 to 85 days (Gomosta and Vergara 1983). Several experiments showed that short-day treatments of seedlings accelerated heading (Roberts and Carpenter, 1962).

The results indicate the possible effect of photoperiod while the plant is in its early growth stage and the possible existence of a very short BVP. 
Photoperiod plays an important role for flower initiation. The number of days to flower with increase in photoperiod number of days to flower gradually increased. The optimum photoperiod was ranged in between $12.1 \mathrm{hrs}$ to $12.2 \mathrm{hrs}$ to enter the crop into reproductive phase (panicle initiation). Thereby it was concluded that optimum photoperiod for completing vegetative phasein rice $c v$. RNR 15048 was ranged in between $12.5 \mathrm{hrs}$ to $12.1 \mathrm{hrs}$.

\section{References}

De Datta, S.K., and Zarate, P.M. 1970. Environmental conditions, growth characteristics, nitrogenase response and grain yield of tropical rice. International Journal of Biometerol.14: 71-89.

Dingkuhn, M., and K. Miezan.1995.Climatic determinants of irrigated rice performance in the Sahel: II. Validation ofphotothermal constants and characterization of genotypes. Agric. Syst. 48: 411-433.

Food and Agricultural Organisation (FAO), FAO Statistical Data Base, http://apps.fao.org/ 2014.

Gomosta, A., and Vergara, B.S. 1983. Photoperiod sensitivity of Rayadarices. Int. Rice Res. Newsl. 8(6):29.

Rahaman, M., 2004. Response of photosensitive rice varieties to nitrogen levels in boro season. Oryza. 41: 101104.

Roberts, E.H., and Carpenter, A.J. 1962. Flowering response of rice to different photoperiods of uniform daily amounts of light radiation. Nature 196:10771078.

Summerfield, R.J., Collinson, S.T., Ellis, R.H., Roberts, E.H and Penning de vries, F.W.T. 1992. Photothermal responses of flowering in rice (Oryza sativa). Annals of Botany. 69:101-112.

Veragara, B.S., and Chang, T.T. 1985.The flowering response of the rice plant to photoperiod. A review of the literature. 61: 104-151.

Vergara, B.S., 1976. Physilological and morphological adaptability of rice varieties to climate. Climate and Rice.67-86.

Vergara, B.S., Puranabhavung, S and. Lilis, R 1965. Factors determining the growth duration of rice varieties. Phyton 22:177-185.

Yin, X., Kropff, M.J., Horie, T., Nakagawa, H., Centeno, H.G.S., Zhu, D and Goudriaan, J. 1997 a. A model for photothermal responses of flowering in rice I. Model description and parameterization. Field Crops Research. 51:189-200.

Yin, X., Kropff, M.J., Nakagawa, H., Horie, T and Goudriaan, J.1997 b. A model for photothermal responses of flowering in rice II. Model evaluation. Field Crop Research. 51: 201-211.

Yoshida, S., 1981. Fundamentals of Rice Crop Science. International Rice Research Institute, Los Banos, Philippines. 269.

\section{How to cite this article:}

Nikitha, K., G. Sreenivas, P. Leela Rani and Madhavi, A. 2018. Performance of Photo Sensitive Rice cv. RNR 15048 (Telangana Sona) Under Varied Nitrogen Levels and Environmental Conditions. Int.J.Curr.Microbiol.App.Sci. 7(3): 3602-3605. doi: https://doi.org/10.20546/ijcmas.2018.703.414 